\title{
Effect of Low Level Laser Therapy on the Repair of Bone Defects Grafted with Inorganic Bovine Bone
}

\author{
Antonio Luiz Barbosa PINHEIRO ${ }^{1}$ \\ Francisco de Assis LIMEIRA JÚNIOR ${ }^{2}$ \\ Marleny Elizabeth Márquez GERBI² \\ Luciana Maria Pedreira RAMALHO ${ }^{3}$ \\ Clovis MARZOLA ${ }^{4}$ \\ Elizabeth Arruda Carneiro PONZI ${ }^{5}$ \\ ${ }^{1}$ Laser Center, School of Dentistry, Federal University of Bahia, Salvador, BA, Brazil \\ ${ }^{2}$ Federal University of Bahia, Salvador, BA, Brazil and Federal University of Paraiba, João Pessoa, PB, Brazil \\ ${ }^{3}$ Department of Diagnostics and Therapeutics, School of Dentistry, Federal University of Bahia, Salvador, BA, Brazil \\ ${ }^{4}$ Department of Surgery, School of Dentistry, University of São Paulo, Bauru, SP, Brazil \\ ${ }^{5}$ School of Dentistry, Federal University of Pernambuco, Recife, PE, Brazil
}

\begin{abstract}
The aim of this study was to assess histologically the effect of LLLT $(\lambda 830 \mathrm{~nm})$ on the repair of standardized bone defects on the femur of Wistar albinus rats which were grafted with inorganic bovine bone Gen-ox ${ }^{\circledR}$. Three randomized groups were studied: group I (control, $n=6)$; group II $\left(\right.$ Gen-ox $\left.{ }^{\circledR}, n=9\right)$ and group III $\left(\right.$ Gen-ox ${ }^{\circledR}+$ LLLT, $\left.n=9\right)$. The animals were irradiated every $48 \mathrm{~h}$ during 15 days; the first irradiation was performed immediately after the procedure. The animals were irradiated transcutaneuosly at four points around the defect. At each point a dose of $4 \mathrm{~J} / \mathrm{cm}^{2}$ was given $(\varnothing \sim 0.6 \mathrm{~mm}, 40 \mathrm{~mW})$ and the total dose per session was $16 \mathrm{~J} / \mathrm{cm}^{2}$. The animals were killed by an overdose of general anesthetic 15, 21 and 30 days after surgery. The specimens were routinely processed by embedding in paraffin, serially cut and stained with H\&E and Picrosirius and analyzed under light microscopy. The results showed evidence of a more advanced repair in the irradiated group when compared to the non-irradiated groups. The repair of the irradiated group was characterized by both increased bone formation and amount of collagen fibers around the graft within the cavity from the 15 th day after surgery, also considering the osteoconductive capacity of the Gen-ox ${ }^{\circledR}$. We conclude that LLLT had a positive effect on the repair of bone defects implanted with inorganic bovine bone.
\end{abstract}

Key Words: LLLT, bone repair, inorganic bovine bone.

\section{INTRODUCTION}

Bone loss may be a result of various pathologies, trauma or a consequence of surgical procedures. This has led to extensive studies on the process of bone repair worldwide. Several techniques for the correction of bone defects have been proposed, amongst them, the use of several types of grafts, membranes, or the association of both techniques.

The use of inorganic bovine bone is not a new tool to improve bone repair as there are reports as early as 1889 (1). This material was used previously for the reconstruction of alveolar ridge (2), bone loss associated to both periodontal and periapical lesions (3), on bone defects (4) and as a hemostatic agent (1).

Although the use of low-level laser therapy (LLLT) on the biomodulation of bone repair has been growing steadily and several studies have demonstrated positive results on the healing of bone tissue $(6,7)$, there are no previous reports on the association of LLLT and biomaterials. The aim of this study was to assess the effect of LLLT on the healing of bone defects treated with inorganic bovine bone.

\section{MATERIAL AND METHODS}

Twenty-four young adult healthy male and female Wistar albinus rats (weight 270-320 g) were kept

Correspondence: Dr. Antonio Pinheiro, Faculdade de Odontologia, Universidade Federal da Bahia, Av Araújo Pinho, 62, Canela, 40110-150 Salvador, BA, Brasil. e-mail: albp@ufba.br or flimeira@ccs.ufpb.br 
under natural conditions of light, humidity and temperature at the Animal Experimentation Laboratory of the School of Dentistry of the Federal University of Bahia, Brazil. The animals were fed with laboratory diet and water ad libitum. The animals were divided into three groups: group I: control $(\mathrm{N}=6)$; group II: inorganic bovine bone ( $\mathrm{n}=9)$; group III: inorganic bovine bone + LLLT $(n=9)$. Each group was then divided into three subgroups $(15,21$ and 30 days).

Under intraperitoneal general anesthesia $(10 \%$ chloral hydrate, $0.4 \mathrm{ml} / 100 \mathrm{~g}$ ), the right leg of the animals was shaved and the femur exposed. Standardized $3 \mathrm{~mm}^{2}$ cavities were created on the superior third of the lateral side of the bone. In group I, the periosteum was repositioned and sutured with catgut and the skin closed with nylon. In groups II and III, the cavities were completely filled with inorganic bovine bone (Gen$\mathrm{ox}^{\circledR}$; Baumer S/A, Mogi Mirim, SP, Brazil). All wounds were routinely sutured as described previously. The animals of group III were submitted to 7 sessions of LLLT ( $\lambda 830 \mathrm{~nm}, 40 \mathrm{~mW}$, Ø 0.60 mm, CW; Thera Lase, DMC Equipamentos, São Carlos, SP, Brazil), at 48-h intervals. The irradiation was performed transcutaneously and the first session was performed immediately after surgery. A dose of $4 \mathrm{~J} / \mathrm{cm}^{2}$ was applied to 4 points around the defect giving a total of $16 \mathrm{~J} / \mathrm{cm}^{2}$ per session and a total treatment dose of $112 \mathrm{~J} / \mathrm{cm}^{2}$. This was based on previous studies (8) recommending doses ranging from 1.8 to $5.4 \mathrm{~J} / \mathrm{cm}^{2}$. The animals were killed 15,21 and 30 days after surgery by an overdose of general anesthetic. Samples were taken and kept on $4 \%$ buffered paraformaldeyde solution for 5 days. The samples were decalcified with $10 \%$ nitric acid and routinely stained with H\&E and Picrosirius (9).

\section{RESULTS}

Light microscopy showed that at day 15 the cavity of group I (control) was filled by bone marrow and a few bone trabeculae. The cortical defect was more pronounced 21 days after surgery and nearly closed at day 30 (Figure 1).

In group II $\left(\mathrm{Gen}-\mathrm{ox}^{\circledR}\right)$, the graft filled nearly the entire cavity and was encircled by collagen fibers 15 days after surgery. Immature bone trabeculae were observed at the graft surface but no newly formed bone around the graft could be seen at this time. Up to day 30 after surgery, the graft particles were evenly distributed in the cavity and were partially or totally encircled by newly formed bone. Newly formed bone trabeculae were seen initiating repair of the cortical region (Figure 2).

Fifteen days after surgery, specimens of group III (Gen-ox ${ }^{\circledR}+$ LLLT) showed that the graft filled most of the cavity and was also encircled either by collagen fibers or mineralized newly formed bone. At the cortical region, some neoformed bone trabeculae around some particles of the graft and a dense amount of collagen fibers could be observed. Twenty-one days after surgery, an increased amount of neoformed bone could be seen and the graft was encircled by collagen fibers. At the end of the experimental period, the cavity was still filled by the graft and the area was densely filled by collagen fibers (Figure 3 ).

\section{DISCUSSION}

It seems clear from the results that Gen-ox ${ }^{\circledR}$ has osteoconductivity because all grafted specimens showed
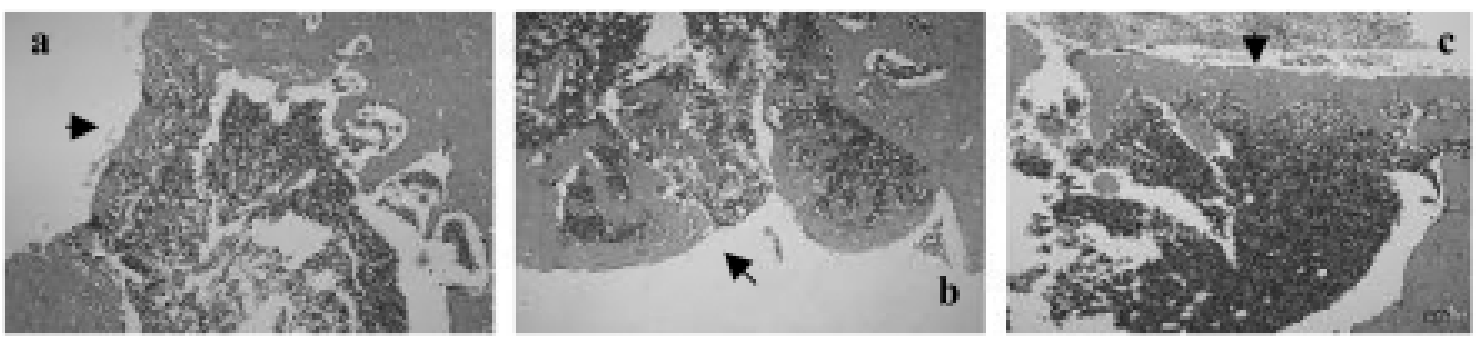

Figure 1. Photomicrography of control group. Left: At day 15, there was discrete bone formation at the cortical defect (arrow). Middle: At day 21, the deposition of new bone at the cortical region was more evident (arrow). Right: At day 30, there was a complete union of the cortical region (arrow). H\&E. Original magnification: approximately 40X. 
bone neoformation around the particles. It is interesting to observe that most specimens showed the particles of the graft enclircled by collagen fibers and filling the center of the cavity at day 15 . At day 21 , these particles were unevenly distributed and were encircled by a variable amount of newly formed bone. The level of bone neoformation did not change much up to day 30 in most groups.

It is accepted that although this material has osteoconductivity, the repair of the defect may be slow because of the need for the graft to be reabsorbed, slowing down the process. In this study, the presence of macrophages and giant cells around the particles, as observed previously $(2,10)$, may explain the reduction of the amount of particles throughout the experimental time. On the other hand, a previous report suggested that this type of material may also be incorporated into the newly formed bone $(4,5)$.

It is clear that the use of the graft prevents the formation of fibrosis of the lesion and also protects the cavity (4) and acts as a framework for the deposition of neoformed bone (11).

Although the biomodulatory effect of LLLT on bone regeneration was observed previously under different experimental conditions and the results observed in these studies $(6,7)$ are aligned with the ones of the present investigation, others have found no effect $(12,13)$. This may be due to several aspects of the design of the experiment.

It is important to also consider the systemic effect of LLLT (14), which was not considered in some previous reports in which no effects of LLLT were found (16). Other reports used very low doses (12). The use of inappropriate wavelengths may also result in negative results (12). Higher wavelengths are more resistant to dispersion than lower ones and deeply penetrate the skin (15). It has been reported that 632.8 $\mathrm{nm}$ laser light penetrates $0.5-1 \mathrm{~mm}$ before losing $37 \%$

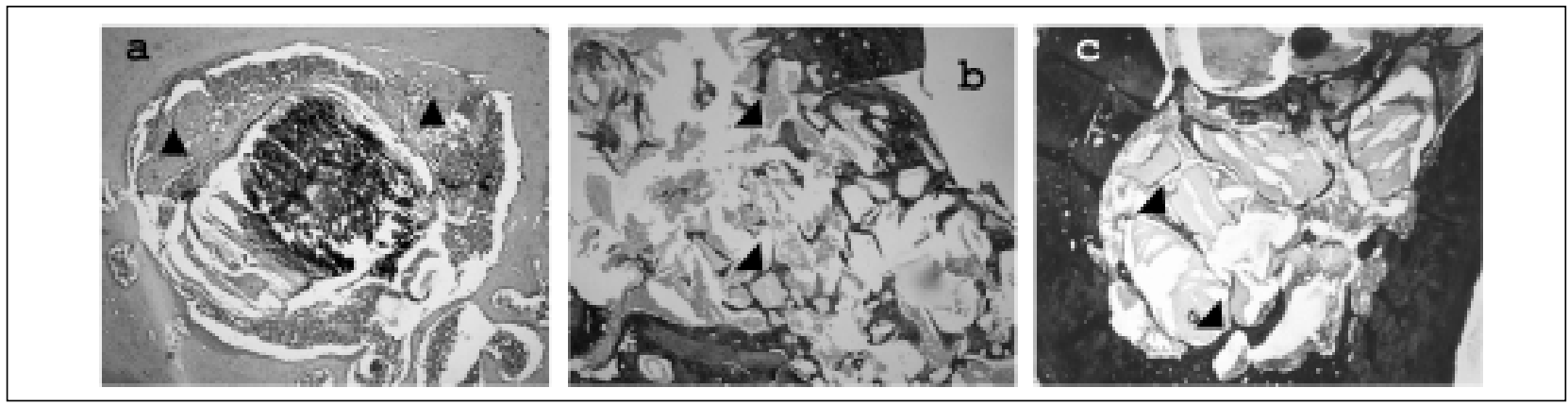

Figure 2. Photomicrography of group II. Left: At day 15, cortical repair was observed and also the presence of delicate newly formed bone within the cavity near the graft surface (arrowheads). At days 21 (middle) and 30 (right), newly formed bone could be seen around the graft (arrowheads). Left panel: H\&E; middle and right panels: Picrosirius. Original magnification: approximately 40X.
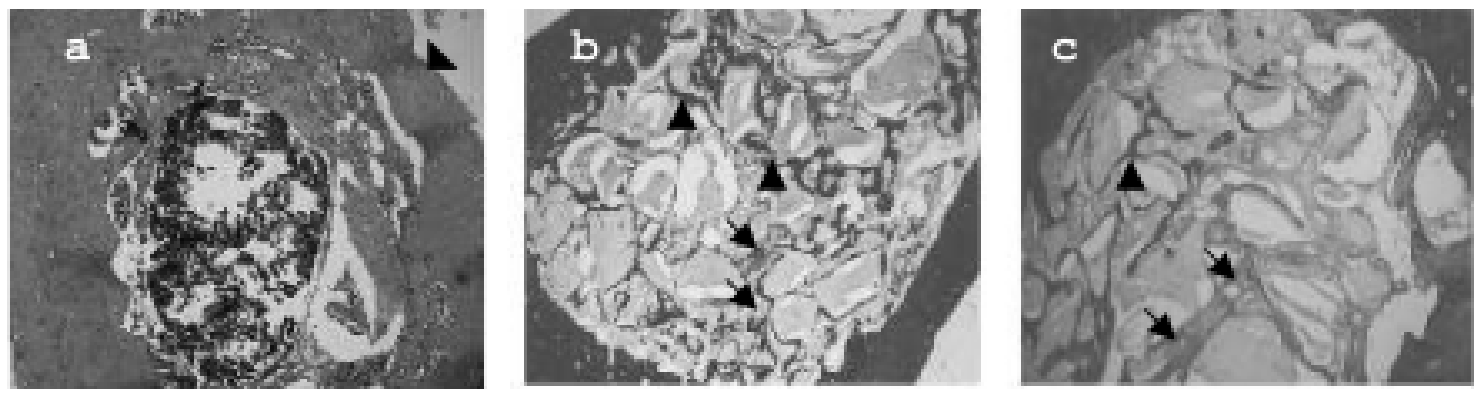

Figure 3. Photomicrography of group III. Left: At day 15, complete cortical repair was observed (arrowhead). At days 21 (middle) and 30 (right), newly formed bone could be seen (arrowheads) and also collagen fibers encircling the graft (arrows); Left panel: H\&E; middle and right panels: Picrosirius. Original magnification: approximately $40 \mathrm{X}$. 
of its intensity (16). On the other hand, infrared wavelengths penetrate $2 \mathrm{~mm}$ before losing the some percentile of energy. This is a clear indication for the use of infrared laser light on bone tissue. However, systemic effects may not be disregarded when visible laser light is used.

The presence of large amounts of collagen fibers on irradiated specimens was the major finding in these groups and this may represent an early effect of the LLLT on repair as other studies demonstrated increased collagen production following LLLT (17). As collagen is an important component of the extracellular matrix of bone and increased amounts, as seen in this study, may indicate a positive effect of LLLT on bone healing despite the fact that in some specimens there was no difference in the amount of newly formed bone between the irradiated group and controls. It is necessary to consider that a large amount of collagen fibers will represent an increased bone neoformation after mineralization of the matrix. The mechanism by which LLLT interferes in collagen synthesis is not fully understood; however, it may be because of alterations in the genetic regulation or in the modulation of enzymatic activity involved in the metabolism of the collagen as suggested previously (17).

It is uncertain whether biomodulation of bone formation is an overall effect on mesenchymal cells or a direct stimulation of osteoblasts. It is possible that the observed results in irradiated specimens are due to an increased release of growth factors, mainly fibroblast growth factor, which is found in bone tissue and acts on differentiated cells increasing both cell proliferation and secretion of components of the matrix (18).

The doses used in this study are in agreement with several previous reports that suggested that $1-5 \mathrm{~J} / \mathrm{cm}^{2}$ induces positive effects on both bone and soft tissues $(6-8,17)$. It is important to note that four points of irradiation were used to fractionate the total dose per session. The points of irradiation around the defect were chosen because the results of irradiation of the graft would be uncertain. The presence of the particles would make the diffusion of light into the tissues more difficult.

A total dose per session of $16 \mathrm{~J} / \mathrm{cm}^{2}$ is in accordance with the clinical parameters recommended by Pinheiro et al. (8). The literature shows that biomodulatory effects are dose dependent (19). It is also recognized that other factors such as the phase of cell growth
(20) and the frequency and number of sessions (7) also influence the final result of the use of LLLT.

When groups II and III were compared, it was evident that bone neoformation was similar at day 15 . However, at days 21 and 30, bone formation was more evident in both the core of the cavity and in the cortical region. Although irradiated specimens showed a dense deposition of collagen fibers around the particles in the core of the defect and at the cortical region, the same was not detected in control specimens, especially in the core of the defect.

We conclude that LLLT had a positive biomodulatory effect on the repair of bone defects implanted with inorganic bovine bone.

\section{RESUMO}

O objetivo deste trabalho foi avaliar histologicamente a influência da radiação laser não-cirúrgica $(\lambda 830 \mathrm{~nm})$ sobre o reparo ósseo de defeitos padronizados em fềmur de ratos Wistar albinus e submetidos a implante de osso bovino inorgânico Gen-ox ${ }^{\circledR}$. Foram estabelecidos três grupos de animais: grupo I (controle, $\mathrm{n}=06)$; grupo II $\left(\right.$ Gen-ox $\left.{ }^{\circledR}, \mathrm{n}=09\right)$ e grupo III $\left(\right.$ Gen-ox ${ }^{\circledR}+$ LLLT, $\mathrm{n}=09$ ). Os animais foram irradiados a cada 48 horas, sendo a primeira irradiação realizada imediatamente após a cirurgia. Os animais foram irradiados transcutaneamente em quatro pontos em torno da ferida. Cada ponto recebeu uma dose de $4 \mathrm{~J} / \mathrm{cm}^{2}$ (Ø 0,6 mm, $40 \mathrm{~mW}$ ) e a dose total por sessão foi de $16 \mathrm{~J} / \mathrm{cm}^{2}$. Os sacrifícios foram realizados 15,21 e 30 dias após a cirurgia. Os espécimes foram removidos e fixados para procedimento laboratorial, sendo corados com H\&E e Picrosirius e analisados em microscopia de luz. Os resultados mostraram evidência de um reparo ósseo mais avançado nos espécimes irradiados em relação aos não irradiados. $\mathrm{O}$ reparo nos espécimes irradiados foi caracterizado por uma maior neoformação óssea, bem como por uma maior proliferação de fibras colágenas no interior do defeito já a partir de 15 dias após a cirurgia, também considerando a capacidade osteocondutiva do Gen-ox ${ }^{\circledR}$. Conclui-se que a LLLT resultou num efeito de biomodulação positiva sobre o reparo do defeito ósseo submetido a implante de osso bovino inorgânico.

\section{REFERENCES}

1. Rios ALBB, Barbosa CEM, Abi Rached RSG, Gabrielli MFR, Okamoto T. Comportamento biológico de implantes de osso bovino anorgânico em arco zigomático de ratos. Estudo histológico. Rev Odontol Univ Est São Paulo 1996;25:87-101.

2. Pinholt EM, Bang G, Haanaes HR. Alveolar ridge augmentation in rats by Bio-Oss. Scand J Dent Res1991;99:154-161.

3. Simonpietri JJ, Novaes AB, Batista Júnior EL, Filho EJ. Guided tissue regeneration associated with bovine-derived anorganic bone in mandibular class II furcation defects. 6-month results at re-entry. J Periodontol 2000;71:904-911.

4. Batista PS. Avaliação microscópica do processo de reparo em cavidades ósseas submetidas a implante de osso liofilizado bovino 
$\left(\right.$ Bio-Oss $\left.{ }^{\circledR}\right)$ em fêmur de ratas. [Master's thesis]. Porto Alegre: Faculdade de Odontologia, Pontifícia Universidade Católica do Rio Grande do Sul; 1999. 85p.

5. Batista Júnior EL, Novaes Júnior AB, Simonpietri JJ, Batista FC. Use of bovine-derived anorganic bone associated with guided tissue regeneration in intra-bony defects. Six-month evaluation at re-entry. J Periodontol 1999;70:1000-1007.

6. Pinheiro ALB, Oliveira MAM, Martins PPM. Biomodulação da cicatrização óssea pós-implantar com o uso da laserterapia nãocirúrgica: Estudo por microscopia eletrônica de varredura. Rev FOUFBA 2001;22:12-19.

7. Silva Júnior AN, Pinheiro ALB, Oliveira MG, Weismann R, Ramalho LM, Nicolau RA. Computerized morphometric assessment of the effect of low-level laser therapy on bone repair: an experimental animal study, J Clin Laser Med Surg 2002;20:8387.

8. Pinheiro ALB. Low-level laser therapy in management of disorders of the maxillofacial region. J Clin Laser Med Surg 1997;15:181-183.

9. Junqueira LCU, Bignolas G, Brentani RR. Picrosirius staining plus polarization microscopy, a specific method for collagen detection in tissue sections. Histochem J 1979;11:447-455.

10. Sanches MG, Okamoto T, Carvalho ACP. Processo de reparo em feridas de extração dental após implante de "osso anorgânico" Estudo histológico em ratos. Rev Fac Odont Araçatuba 1972;1:83-90.

11. Garbin CM, Garbin NM. Enxertos Ósseos e Regeneração Tecidual Guiada: Noções Básicas. São Paulo: Pancast, 1994.

12. David R, Nissan M, Cohen I, Soudry M. Effect of low-power He-
Ne laser on fracture healing in rats. Lasers Surg Med 1996;19:458-464.

13. Lagan KM, Clements BA, McDonough S, Baxter GD. Low intensity laser therapy $(830 \mathrm{~nm})$ in the management of minor postsurgical wounds: a controlled clinical study. Lasers Surg Med 2001;28:27-32.

14. Rockhind S, Rousso M, Nissan M, Villarreal M, Barr-Nea L, Rees DG. Systemic effects of low-power laser irradiation on the peripheral and central nervous system, cutaneous wounds and burns. Lasers Surg Med 1989;9:174-182.

15. Kolárová H, Ditrichová D, Wagner J. Penetration of the laser light into the skin in vitro. Lasers Surg Med 1999;24:231-235.

16. Basford JR. Low-intensity laser therapy: still not an established clinical tool. Lasers Surg Med 1995;16:331-342.

17. Reddy GK, Stehno-Bittel L, Enwemeka CS. Laser photostimulation of collagen production in healing rabbit achilles tendons. Lasers Surg Med 1998;22:281-287.

18. Sigurdsson TJ, Lee MB, Kubota K, Turek TJ, Wozney JM, Wikesjö UME. Periodontal repair in dogs: recombinant bone morphogenetic protein-2 significantly enhances periodontal regeneration. J Periodontol 1995;66:131-138.

19. Kipshidze N, Nikolaychik V, Keelan MH, Shankar LR, Khanna A, Komowsky R, Leon M, Moses J. Low-power helium:neon laser irradiation enhances production of vascular endothelial growth factor and promotes growth of endothelial cells in vitro. Lasers Surg Med 2001;28:355-364.

20. Osawa Y, Shimizu N, Kariya G, Abiko Y. Low-power laser irradiation stimulates bone nodule formation at early stages of cell culture in rat calvarial cells. Bone 1998;22:347-354.

Accepted November 26, 2002 